\title{
Hydrological modeling of a detention reservoir: flood control and aquifer recharge
}

\section{Modelagem hidrológica de uma lagoa de detenção: controle de cheias e recarga de aquífero}

\author{
Antônio Marozzi Righetto ${ }^{1}$ and Bruno Freitas ${ }^{1}$ \\ ${ }^{1}$ Universidade Federal do Rio Grande do Norte, Natal, RN, Brasil \\ E-mails: antmarrig@yahoo.com.br (AMR),brunofreitas@uol.com.br (BF)
}

Received: April 04, 2016 - Revised: June 01, 2016 - Accepted: July 24, 2016

\begin{abstract}
In this paper, we proposed studying a small urban drainage catchment, named Pilot Basin of Mirassol (PBM) in Natal, RN - Brazil whose outlet is a detention and infiltration reservoir (DIR). The rainfall-runoff transformation processes, water accumulation in DIR and the process of infiltration and percolation in the soil profile until the free aquifer were modeled; and, from rainfall event observations, water levels in DIR, free aquifer water level measurements, and also, parameter values determination, it was able to calibrate and modeling these combined processes. The mathematical modeling was carried out from the use of a distributed rainfall-runoff model, and besides, we developed a model to simulate the soil percolation in an unsaturated porous media. Continuous simulation was run over a period of eighteen months in time intervals of one minute. The generated hydrographs were transformed into inlet volumes to the DIR and then, it was carried out water balance in these time intervals, considering infiltration and percolation of water in the soil profile. As a result, we obtain an evaluation on the storage water process in DIR as well as the infiltration of water, redistribution into the soil and the groundwater aquifer recharge, in continuous temporal simulation. We found that the DIR has good performance in order to storage storm water (floods) and contributing to the local aquifer recharge process.
\end{abstract}

Keywords: Rainfall-discharge model; Unsaturated soil; Phreatic groundwater; Numerical simulation.

\section{RESUMO}

Neste trabalho, se propôs estudar uma pequena bacia de drenagem urbana, a bacia piloto de Mirassol (BPM), em Natal, RN, que tem como exutório uma Lagoa de Detenção e Infiltração (LDI). Os processos de transformação da chuva em vazão, a acumulação de água na LDI e o processo de infiltração e percolação no perfil do solo até o lençol freático foram modelados e, através de observações dos eventos chuvosos, níveis de água na lagoa e do lençol freático, assim como levantamento de parâmetros, possibilitaram a modelagem desses processos combinados. A modelagem matemática foi realizada com o uso de um modelo distribuído chuva-vazão e a elaboração de um modelo de percolação em meio insaturado. Foi realizada a simulação contínua ao longo de um período de dezoito meses, com intervalos de tempo de um minuto. Os hidrogramas gerados foram transformados em volumes afluentes à lagoa e então, realizado o balanço hídrico nesses intervalos de tempo, considerando-se a infiltração e percolação de água no perfil do solo. Como resultado, obteve-se a avaliação da LDI no processo de armazenamento de água, assim como a infiltração, redistribuição de água no solo e a recarga ao aquífero freático, possibilitando simular a sequência temporal de distribuição. Com as simulações realizadas, verificou-se o bom desempenho da LDI na absorção de cheias e sua contribuição no processo de recarga do aquífero local.

Palavras-chave: Modelo chuva-vazão; Solo insaturado; Lençol freático; Simulação numérica. 


\section{INTRODUCTION}

Disorderly and intense occupation of urban areas without integrated planning of various infrastructures for sustainable development has increased drainage problems during heavy rain events. This fact is notorious especially in areas of periphery or suburban, mainly for lack of efficient planning usually observed in Brazilian urban catchments.

The occurrence of urban territorial expansion coupled with the lack of enforcement of following appropriate legislation and supervision to ensure proper disciplining of soil use and occupation is an inducer of flooding problems.

Drainage problem distributes along the natural lines of surface runoffs, which depends strongly on catchment topography and waterproofing degree (RIGHETTO et al., 2009a).

New conceptions for urban drainage regarding the use of hygienists systems and urban compensatory techniques to counter balance waterproofing by green areas and the use of lower topographic areas as local accumulation of drainage water are recently being discussed and applied.

Thus, the spread of the concept and application of low-impact techniques in providing urban drainage come gradually changing urban drainage systems, particularly when there is integration between urban infrastructure and city landscape adaptations.

The approach called LID - Low Impact Development, is currently being applied and discussed in its various aspects of using by professionals of urban drainage area (SOUZA; CRUZ; TUCCI, 2012; TAVANTI; BARBASSA, 2012; REZENDE; MIGUEZ; VERÓL, 2013; AMANTHEA; NASCIMENTO, 2015).

In the city of Natal, several natural lakes such as New Lagoon (Lagoa Nova), Dry Lagoon (Lagoa Seca), Jacob Pond and Meadow Lagoon (Lagoa da Campina) disappeared. From the 1970s, there was a significant increase in occupancy areas in surrounding of these lakes, by construction of parks, schools, public and home buildings, inducing the transfer of the natural urban drainage system of the city to gallery networks. However, these practices intensified flooding episodes by increasing observed frequencies on road system.

In storm events, these occupied ponds resurface forming flooded areas because they are closed depressions where runoffs are directed as result of intensified waterproofing surface. The reduction of lake surfaces makes them unable to retain large runoff volumes even in more frequent lower rainy events; and thus, causing floods in their neighborhoods.

The Natal city drainage catchments practically are inserted in the municipal territory, because Natal receives small external surface water contribution to their urban area, which can be neglected in the global water balance of the drainage system. For water balance effect, there is a division between Natal drainage areas: open and closed catchments.

According to PDDMA (NATAL, 2009), closed drainage areas without runoff outlets are located in the western and southern areas of the city, including the catchments of Dunes Park, Jaguarari Lagoon, San Vale / Satellite City and Lagoinha, with total drainage area of $3,787.2 \mathrm{ha}$, corresponding to $26.7 \%$ of the city territory.

Hydrogeological characteristics of most existing drainage areas in Natal - drainage basins closed with permeable soils, favoring the development of practical induction infiltration process. These drainage elements of preserving infiltration areas in lots and ponds of detention and infiltration reservoir (DIR) are very efficient to receive water from the public drainage system and promoting induced aquifer recharge.

The DIR are open structures that comprise the macro drainage urban system. The purpose of DIR is to minimize the impact of reducing natural storage capacity of the basin. In general, in closed drainage catchment, the aquifer recharge is enhanced by the drainage system.

With soil sealing, withholdings by detention, infiltration and decreased evapotranspiration, there is increased runoff and, consequently, the volumes that are directed to the DIR. Thus, the DIR also come to be an important instrument for aquifer recharge.

The infiltration is an important hydrological component responsible for the process of transferring surface water into the soil. The ability to infiltration depends on the soil characteristics and the state of moisture content of topsoil in the unsaturated zone (TUCCI, 2007).

By introducing LID in drainage systems, one has to consider the coupling between rainfall/runoff and localized storage/infiltration, taking advantage of depression and green areas to hold runoffs produced in relatively small plots that compose the drainage catchment.

With respect to DIR it is important to characterize the infiltration process that occurs in ponds of the macro drainage systems. This characterization is essential for reservoir dimension determination, its efficiency in flood control and in the estimation of local aquifer recharge.

The motivation for this work was to evaluate the operation of a DIR considering the ongoing process of rainfall-runoff events in the Pilot Basin of Mirassol (PBM), the accumulation of water in DIR, the infiltration, the percolation process and the local aquifer recharge in the Dunas-Barreiras groundwater, an important Natal's water resource.

This work is based on mathematical modeling of rainfall-runoff hydrological processes in the PBM and the infiltration, percolation and recharge in the DIR-M (The Detention and Infiltration Reservoir of Mirassol).

Data surveys were conducted, by monitoring rainfall events, water levels in the reservoir and the aquifer water table. Laboratory tests permitted estimating values for the main parameters of the soil used for modeling.

The integrated rainfall-runoff-storage-percolation-recharge modeling is the main contribution of this work for urban hydrology area. Because it was developed in an urban pilot watershed, the surveys and systematization of observations give solid foundation to study investigative work of the hydrological processes with possible inclusion of qualitative aspects and management in urban watersheds.

The developed mathematical model is sufficiently robust in terms of idealization - topology of the area, parameters considered and estimated from observations and the possibility to widespread use to other watersheds as it has been used among others, for example, by the SWMM application (JAMES; ROSSMAN; JAMES, 2010; LIMA; RIGHETTTO, 2013). 
Its idealization has targeted to achieve applicability in terms of ease of use and amount of information necessary to use the model. Enables introduce storage areas (LID) to reduce runoffs due to the urbanization process. It just need to define blocks or storage lots and allow runoffs street entrance to the interior of these areas.

As a contribution towards the process of storing, infiltration and recharge, the model requires parameters for the recharge process in one-dimensional domain despite a region typically three-dimensional; however, in this case, an adjusted parameter is proposed.

Besides the construction and testing of the integrated model, this study aims to understand the ongoing process of storing and drainage infiltration in a reservoir detention in order to analyze the process of percolation and timely recharge the groundwater aquifer as well as to evaluate DIR efficiency in control flood events.

\section{RAINFALL-DISCHARGE MODEL}

The distributed hydrologic model proposed by Righetto (2014) and applied to urban catchments is composed by water balance and resistance flow equations in a discretized domain formed by cells of the drainage area. The cells are blocks or street section units.

With the sequence of precipitation in time for each time interval (adopted the interval of $1 \mathrm{~min}$ ) it is carried out water balance in each block, taking the precipitated volume, accumulated storage volume and the runoff to the street. Runoff coefficient values vary according to the accumulated water on the block. The larger the volume of water stored, the greater the runoff coefficient. Briefly, the following equations are used for the block modulus:

$$
\begin{aligned}
& C_{q}=C_{\text {max }}-\left(C_{\text {max }}-C_{\text {min }}\right) e^{-a_{l} \cdot H_{\text {arm }}} \\
& H_{\text {arm }}=H_{\text {arm }}^{t-1}+C_{q} \cdot H_{\text {chuva }}-Q_{q} / A_{q} \\
& Q_{q}=A_{q} \cdot \alpha_{q} \cdot H_{\text {arm }}^{\beta_{q}}
\end{aligned}
$$

where: $C_{q}$ : Block runoff coefficient; $C_{\max }$ : Maximum runoff coefficient; $C_{\min }$ : Minimum runoff coefficient; $a_{l}$ : Adjusted parameter; $H_{\text {arm }}$ : Water height in the block, $\mathrm{m} ; Q_{q}$ : Block runoff to street, $\mathrm{m}^{3} / \mathrm{min} ; A_{q}$ : Block area, $\mathrm{m}^{2} ; \alpha_{q}$ and $\beta_{q}$ : Parameters of discharge equation (Manning equation).

The mathematical module for streets consists of taking the contributing flows from adjacent blocks and upstream streets directly linked to a particular street section. In this section, it is carried out water balance in time intervals of 1 minute, taking the direct precipitation, accumulation of water in the gutters and the flow discharged by this street section. The following equations summarize this module:

$$
\begin{aligned}
& \sum Q_{m}+C_{r} . P . A_{r}-Q_{r}\left(H_{r}\right)=a_{2}, A_{r} \cdot\left[f\left(H_{r}\right)-f\left(H_{r}^{t-I}\right)\right] \\
& Q_{r}=\alpha_{r} . H_{r}^{\beta_{r}}
\end{aligned}
$$

where: $Q_{m}$ : Discharge contribution from adjacent upstream street, $\mathrm{m}^{3} / \mathrm{min} ; C_{r}$ : Street tunoff coefficient; $P$ : Rainfall at time interval, $\mathrm{mm} ; A_{r}$ : Hydraulic area of street section; $\mathrm{m}^{2} ; Q_{r}$ : Outlet street discharge, $\mathrm{m}^{3} / \mathrm{min} ; H_{r}$ : Depth of water flow in the street, $\mathrm{mm}$; $a_{2}$ : Adjusted geometric parameter; $f\left(H_{r}\right)$ : Convertion function of depth of water in the street to hydraulic depth taking into account pavement, gutter and sidewalk; $\alpha_{r}=\frac{\sqrt{I_{r}}}{n} \alpha^{\prime}{ }_{r}$ e $\beta_{r}=8 / 3$ : Discharge parameter of Manning equations, where $I_{r}$ is the street slope $(\mathrm{m} / \mathrm{m}), n$ the Manning coefficient and $\alpha_{\mathrm{r}}$ geometric parameter of hydraulic street section.

\section{PERCOLATION MODEL}

The unidimensional water percolation in unsaturated media can be described by Richards's equation (REEDER et al., 1980):

$$
C(\Psi) \frac{\partial \Psi}{\partial t}=\frac{\partial}{\partial z}\left[K(\Psi)\left(\frac{\partial \Psi}{\partial z}-1\right)\right]
$$

where: $\Psi$ : Pressure or suction head, $\mathrm{cm} ; K(\Psi)$ Hydraulic conductivity, $\mathrm{cm} / \mathrm{min} ; C(\Psi)$ : Specific moisture capacity $d \theta / d \Psi, \mathrm{em} \mathrm{cm}^{-1} ; \theta$ : Soil moisture content, $\mathrm{cm}^{3} / \mathrm{cm}^{3} ; z$ : Vertical spatial coordinate, from lagoon basement until soil profile basement, (cm); t: Time, min.

As pointed out Righetto (1998), analytical solutions of Richards's equation are restricted to simple problems. On the other hand, several numerical techniques are available for obtaining numerical solution related to the equation of infiltration, percolation and redistribution of water in the soil. Among the numerical techniques, the present model incorporates finite differences precedure.

Figure 1 shows the discretization domain $\Omega \equiv\left[z: 0 a z_{\text {Máx }}\right]$ containing $N$ cells and $N+1$ nodes, so that each cell i has equal length, denoted $\Delta z$.

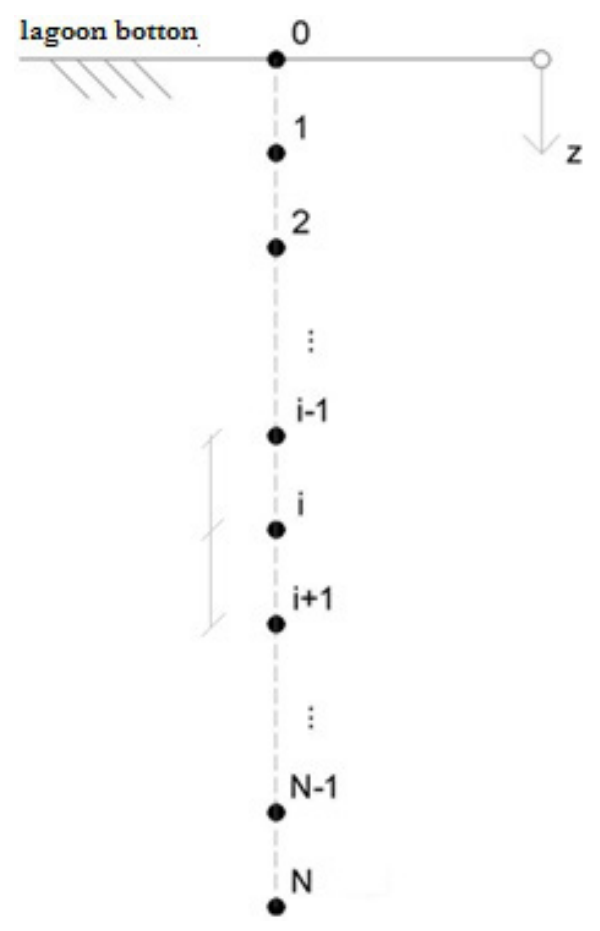

Figure 1. Discretization domain of soil profile. 
The domain was limited at node $\mathrm{N}$ that was located at $3000 \mathrm{~cm}$ (30.0 meters) deep from the pond bottom. It was adopted a constant value for $\Delta z$, equal to $2.0 \mathrm{~cm}$; thus, $N=1500$. This cell size was adequate to ensure stability of the dynamic modeling of water percolation in unsaturated porous profile.

The discretization terms of the Richards equation using the finite difference approach, results in the following algebraic equation:

$C_{i}^{j} \frac{\Psi_{i}^{j+1}-\Psi_{i}^{j}}{\Delta t}=\frac{1}{\Delta z_{i}}\left\{\begin{array}{l}K\left(\Psi_{i+1 / 2}^{j+1 / 2}\right)\left[\left(\frac{\partial \Psi}{\partial z}\right)_{i+1 / 2}^{j+1 / 2}-1\right]- \\ K\left(\Psi_{i-1 / 2}^{j+1 / 2}\right)\left[\left(\frac{\partial \Psi}{\partial z}\right)_{i-1 / 2}^{j+1 / 2}-1\right]\end{array}\right\}$

where:

$$
\begin{aligned}
& \left(\frac{\partial \psi}{\partial z}\right)_{i+1 / 2}^{j+1 / 2}=\frac{1}{2 \Delta z}\left(\Psi_{i+1}^{j+1}+\Psi_{i+1}^{j}\right)-\left(\Psi_{i}^{j+1}+\Psi_{i}^{j}\right) \\
& \left(\frac{\partial \Psi}{\partial z}\right)_{i-1 / 2}^{j+1 / 2}=\frac{1}{2 \Delta z}\left(\Psi_{i}^{j+1}+\Psi_{i}^{j}\right)-\left(\Psi_{i-1}^{j+1}+\Psi_{i-1}^{j}\right) \\
& C_{i}^{j}=\left(\frac{\partial \theta}{\partial \Psi}\right)_{i}^{j}=\frac{d}{d \Psi} \theta\left(\Psi_{i}^{j}\right)
\end{aligned}
$$

$j$ : Time index and $i$ : Space index.

Substituting Equations 8 and 9 into 7 results in an expression that permits the determination of $\Psi_{i}^{j+1}$ through the solution of a tridiagonal linear system (RIGHET'TO, 1998):

$$
-A_{1, i} \Psi_{i+1}^{j+1}+A_{2, i} \Psi_{i}^{j+1}-A_{3,1} \Psi_{i-1}^{j+1}=B_{i}
$$

For internal nodes, $1 \leq i \leq N-1$, the parameters $A_{1, i}, A_{2, i}, A_{3, i}$, e $B_{i}$ are expressed by:

$$
\begin{aligned}
& A_{1, i}=\frac{\Delta t}{2 \Delta z} K\left(\Psi_{i+1 / 2}^{j+1 / 2}\right) \\
& A_{3, i}=\frac{\Delta t}{2 \Delta z} K\left(\Psi_{i-1 / 2}^{j+1 / 2}\right) \\
& A_{2, i}=\frac{\Delta z}{\Delta t} C_{i}^{j}+A_{1, i}+A_{3, i} \\
& B_{i}=A_{1, i} \Psi_{i+1}^{j}+\left(\frac{\Delta z}{\Delta t} C_{i}^{j}-A_{1, i}-A_{3, i}\right) \Psi_{i}^{j}+A_{3, i} \Psi_{i-1}^{j}-\left(A_{1, i}-A_{3, i}\right)
\end{aligned}
$$

Boundary conditions may be of Dirichlet type (specified pressure or suction head) or of Neumann type (specified flux) or of Cauchy type, (flux is a function of the phreatic level position).

The following conditions were adopted in the simulations of this study:

a) Lagoon basement $(z=0)$ :

$$
\begin{aligned}
& A_{1,0}=A_{3,0}=0.00 \\
& A_{2,0}=1.00 \\
& B_{0}=\Psi(0, t)
\end{aligned}
$$

(Dirichlet condition)

It was considered that $\Psi(0, t)$ value can assume field capacity $\Psi_{c c}$ value (lagoon is dry) or $H_{\text {Lagoa }}^{t}$ value (lagoon with storage water). It was supposed that a very low values in relation to field capacity occurred in a very thin soil superficial layer and is not relevant for the determination of soil infiltration.

b) Base condition $1\left(z=z_{\text {max }}\right)$ and depth of phreatic level above 23.00 meters:

$$
\begin{aligned}
& A_{1, N}=1.00 \\
& A_{3, N}=0.00 \\
& A_{2, N}=1.00 \\
& B_{N}=\left(\frac{K\left(\Psi_{i-1 / 2}^{j+1 / 2}\right)-q}{K\left(\Psi_{i-1 / 2}^{j+1 / 2}\right)}\right) \Delta z
\end{aligned}
$$

(Neumann condition)

For this condition, the exploitation discharge value, $\mathrm{q}$, is constant and equal to $0,001 \mathrm{~cm} / \mathrm{min}$, estimated by phreatic water level measurements.

c) Base condition $2\left(z=z_{\text {maxx }}\right)$ and depth of phreatic water level less than $23.00 \mathrm{~m}$ :

$$
\begin{aligned}
& A_{i 1 N}=1.00 \\
& A_{2 N}=1.00 \\
& A_{3, N}=0.00 \\
& q(Z L F)=0.0010+\beta\left[K_{s}-\left(\frac{K_{s} Z L F}{2300}\right)\right] \\
& B_{i}=\left(\frac{K\left(\Psi_{i-1 / 2}^{j+1 / 2}\right)-q(Z L F)}{K\left(\Psi_{i-1 / 2}^{j+1 / 2}\right)}\right) \Delta z
\end{aligned}
$$

(Cauchy condition)

where: $\beta$ : Adjusted parameter for lateral percolation; $K_{s}$ : Saturated hydraulic conductivity, $\mathrm{cm} / \mathrm{min} ; Z L F$ : Phreatic water level depth, $\mathrm{cm}$.

The base boundary condition 2 was implemented because model tests show that base boundary condition 1 (constant exploitation flow) after a certain volume of infiltrated water was not enough for decreasing water table and then, allowing soil profile to become completely saturated.

However, this situation is not observable. It is known that the local aquifer recharge forms a saturated cone-shaped profile and the horizontal lateral flow intensify with decreasing the depth of the regional water table. So it was introduced a law to estimate the discharge of exploitation or flow redistribution side, taking a linear growth as the groundwater level rise relative to regional water level, estimated as equal to $23,00 \mathrm{~m}$. For this case, the flow redistribution was defined by the expression:

$q^{\prime}=\beta_{1}\left[K_{s}-\left(\frac{K_{s} Z L F}{2300}\right)\right]$

where: $\beta_{l}$ is an adjusted parameter; $K_{s}$ is the saturated hydraulic conductivity ( $\mathrm{cm} / \mathrm{min}) ; Z L F$ phreatic water table depth $(\mathrm{cm}$.)

System of equations in finite differences together initial and boundary conditions is solved to determine the pressure or suction head distribution, which permits to determine the moisture distribution as a function of time and thus, allowing to simulate 
the movement of soil water. No special procedure is required in the saturated soil zone, because in this case, $\mathrm{C}(\Psi)$ becomes equal to zero and the Richards model reduces to a Laplacian. For each time step, the system of equations to be solved consists of a tridiagonal linear system of equations; in this work, solved by Thomas algorithm elimination method.

\section{RESERVOIR WATER BALANCE}

Matched to the unidimensional flow model in unsaturated porous media (percolation model) there is the model for water balance of water stored in the reservoir. Processing rainfall-discharge model one obtains water inlet volume to the IDR, $V_{a}^{t}$ along time (eighteen months at time intervals of one minute).

Dividing this amount by the reservoir water surface area at time t, the increase in height, $\Delta h^{t}$, due to this affluent volume is obtained.

For each time, $t$, it is used the value of the hydraulic conductivity, $K_{l}^{t}$ and the heads $\Psi_{0}^{t}, \Psi_{l}^{t}$ referring respectively to the surface of the discretization node (lake bottom) and the adjacent node of the first layer or soil profile cell. The infiltration is determined by Darcy's equation:

$F^{t}=\frac{K_{(0, t)}+K_{(1, t)}}{2} \cdot\left(\frac{\Psi_{(0, t)}-\Psi_{(1, t)}}{\Delta z}+1\right)$

where: $F^{t}$ is the infiltration at time $\mathrm{t}\left(\mathrm{cm} \cdot \mathrm{min}^{-1)}\right.$.

After calculation of infiltration, water balance in DIR is obtained by the following water balance equation:
$H_{\text {Lagoa }}^{t}=H_{\text {Lagoa }}^{t-1}+\Delta h^{t}-F^{t}$

where: $H_{\text {Lagoa }}^{t}$ : Water level in reservoir at time $t,(\mathrm{~cm}) ; \Delta h^{t}$ : Incremental height at time interval between t e $\mathrm{t}+\Delta \mathrm{t}$, (cm).

\section{STUDY AREA}

The Mirassol pilot basin (PBM) is located near Federal University of Rio Grande do Norte and has been studied since 2003 (RIGHETTTO et al., 2009b).

Figure 2 illustrates the drainage area of Mirassol pilot basin, with the location of the DIR, object of this study. The pilot basin is fully urbanized, occupied by residential of middle class and located in Capim Macio neighborhood, south of Natal, RN. Figure 3 shows the watershed delineation and it is topography.

PBM relief is representative of the region with predominant lacustrine formation associated with the presence of dunes. The layer of topsoil, frankly sandy, has high infiltration rates. The soil horizon $B$ is characterized by a lower permeability profile called Barreiras and is an important aquifer water supply of the city. As a whole, the region has high water storage capacity due to the presence of Dunas-Barreiras aquifer. The basin area is 0.14 square kilometers with a maximum elevation of 61.10 meters and altitude at the downstream end of 34.90 meters.

Runoff is directed to a DIR (Mirassol lagoon), which is situated in the region with topographic elevation lower than other areas of the catchment.

There is only one small length drainage collectors, located a few dozen meters upstream this reservoir. The entrance of flow

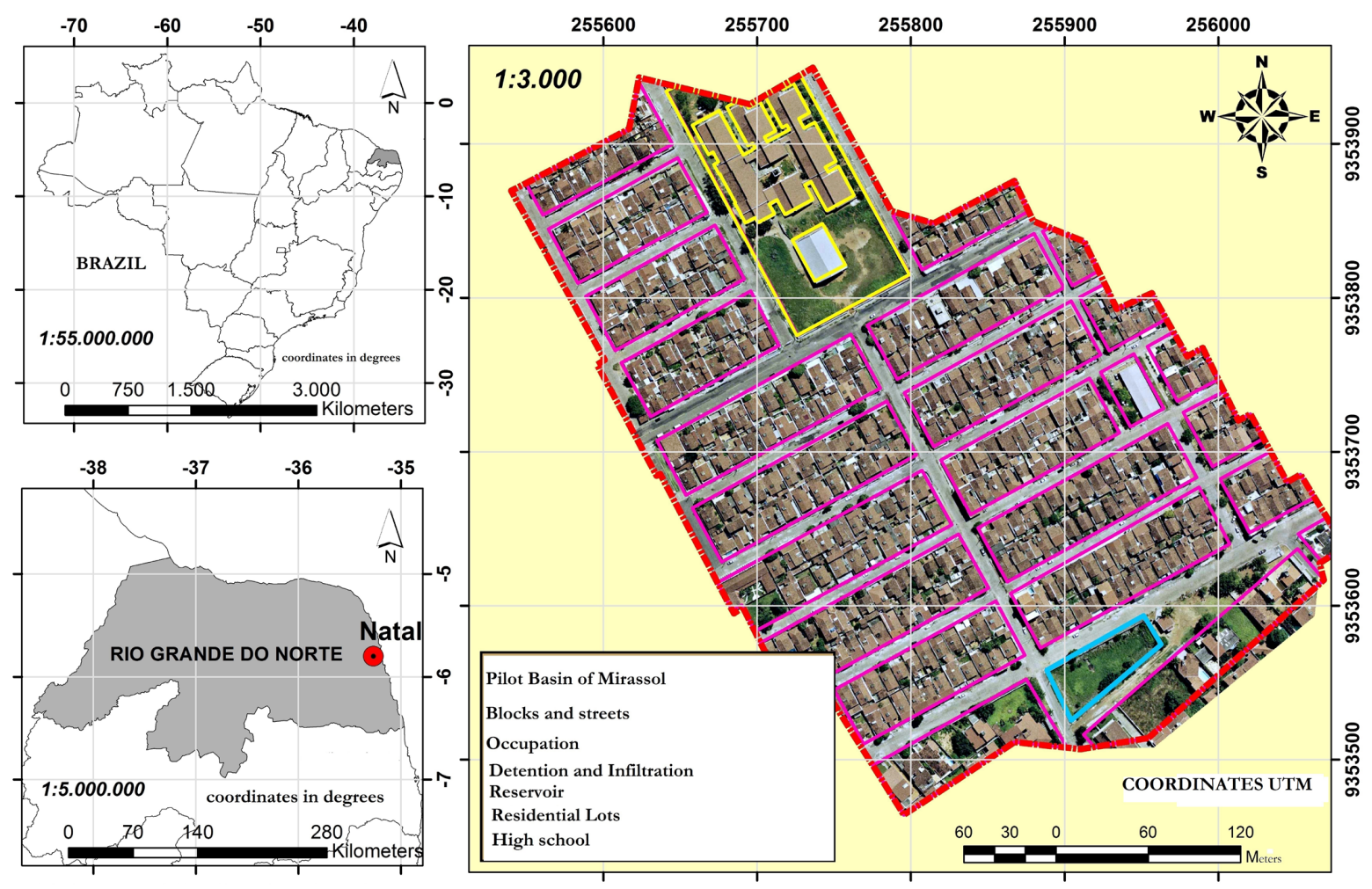

Figure 2. Location of the Pilot Basin of Mirassol (PBM). Source: Righetto et al. (2009b). 
is through open small channel connect to a $1.00 \mathrm{~m}$ diameter pipe (RIGHETTO et al., 2009b).

Above maximum height, surplus water is transferred through a gallery section connected to another reservoir located downstream of the studied lagoon.

As foregoing mentioned, the standard occupancy of MPR is single residential -family, class type $\mathrm{B}$ and $\mathrm{C}$, with predominance of $200 \mathrm{~m}^{2}$ lot area (LIMA, 2011). It is noteworthy that those single residential buildings densely occupy the entire area.

\section{DATA COLLECT}

\section{Blocks and streets runoff coefficients}

Runoff coefficient values used in rainfall-discharge modeling were initially estimated as recommended by the Manual of Drainage Plan Director of Natal, as indicated in Table 1.

For street sections with asphalt, paving it adopted a runoff coefficient of 0.90 was adopted. For the other street sections of the basin, the pavement is covered with cobblestones and, then, a

Table 1. Runoff coefficients.

\begin{tabular}{lc}
\hline \multicolumn{1}{c}{ Occupation } & C \\
\hline Well drained sandy soil & $0.0-0.10$ \\
Lawn & $0.10-0.20$ \\
Plot with x (\%) waterproofed & $(0.6 \mathrm{x}+20) / 100$ \\
Porous pavement & $0.40-0.70$ \\
Asphalt pavement & $0.90-0.95$ \\
\hline
\end{tabular}

runoff coefficient of 0.50 was considered. For Block 1 (considered atypical) it was performed a weighted average of various surfaces that have been identified (roofs, green areas and permeable paving) resulting in a runoff coefficient of 0.27 .

For the other blocks, it was preliminarily considered values of runoff coefficients suggested by PDDMA (NATAL, 2009) for high percentage waterproofed lots.

By default occupancy and aerial photos analysis, it was considered that the blocks are $85 \%$ waterproofed resulting in a runoff coefficient of 0.71 . These values were adopted preliminary as runoff coefficient $(\mathrm{C})$ and after altered within a range $(\mathrm{Cmin}$ and Cmax) based on calibration simulations of PBM rainfalldischarge modeling.

\section{Precipitation data}

The rainfall data were obtained from an automatic rainfall station located within a public area - the State School Floriano Cavalcanti (Floca), inserted in the drainage basin of this study. The observation period began in April 2014 and ended in September 2015, with storage resolution of one minute.

\section{PBM geometry}

PBM has been schematically discretized (spatially) as illustrated in Figure 4 in order to define the topology and numbering blocks and street sections.

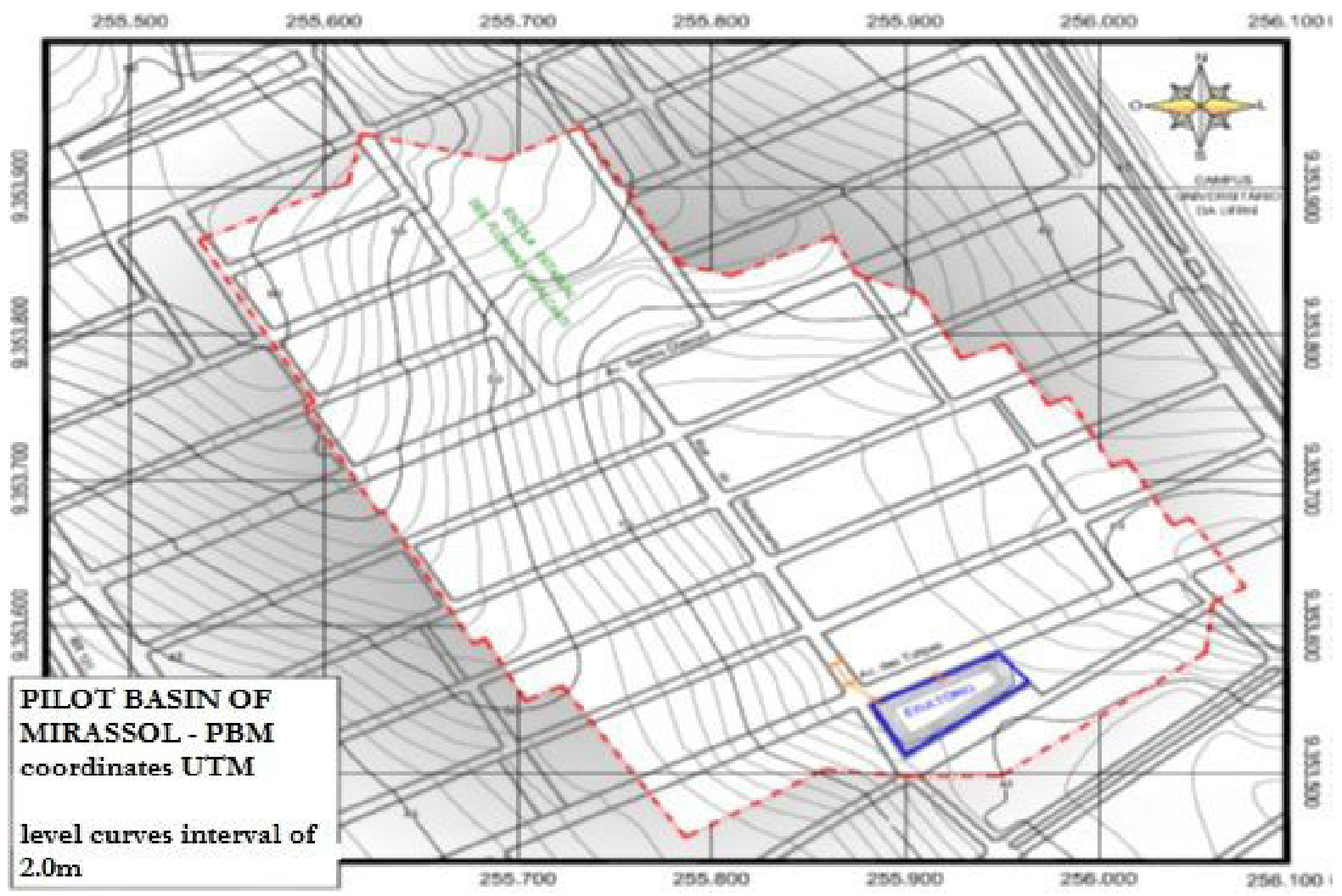

Figure 3. Delineation of the PBM area. 
Figure 4 shows numbered street segments belonging to PBM, as well as the blocks that comprise it. The arrows indicate the direction of the lines of surface runoff. The sections 43 and 44 represent the end sections that flow into the DIR-Mirassol.

Geometrical characteristics (length, width and slope) of the streets and blocks were obtained from drainage register of the Master Plan of Natal Management and Drainage System.

\section{Reservoir geometry}

Drainage system plan of Natal city (NATAL, 2009) provides a map in CAD composed of contour lines. From this map and field validation, the extracted dimension-volume relation was obtained and adjusted a parabolic function for water volume of water stored in the DIR. The reservoir water level has a maximum

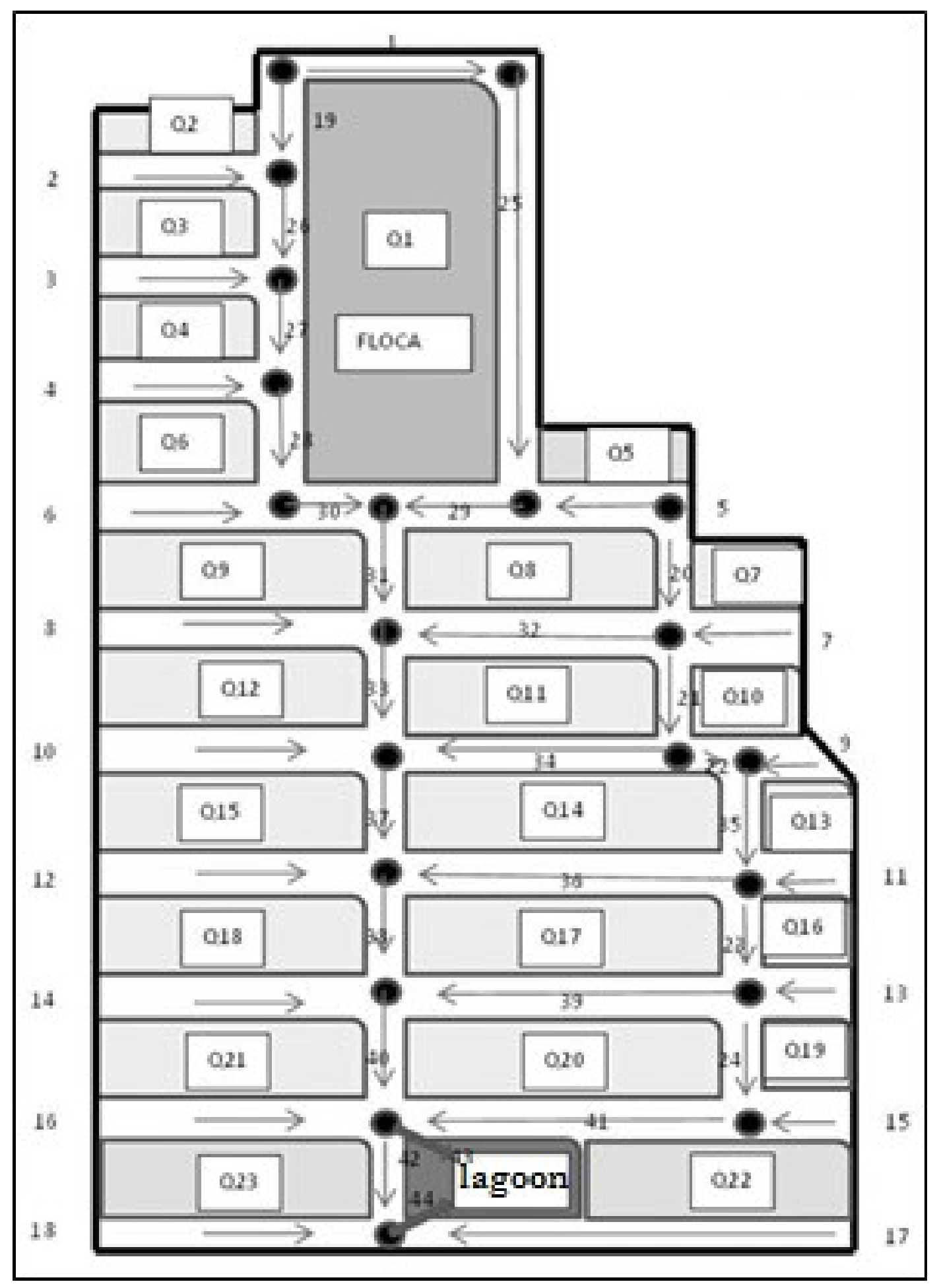

Figure 4. Spatial discretization of PBM. 
value of $3.50 \mathrm{~m}$, which corresponds to the volume of water stored equal to $4,450 \mathrm{~m}^{3}$. This level defines the reservoir overflow outlet, which transfers the surplus to another DIR.

\section{Soil physical properties}

Firstly, it was performed granulometric test with three soil samples taken from the reservoir bottom at depths soil profile of 2 , 4 and 6 meters. The tests permit to conclude that the three samples have similar particle size distributions. Thus, the measurements indicated that the average sand, silt and clay are approximately $84 \%, 11.5 \%$ and $4.5 \%$, respectively. With these average values and making use of the triangle textural classification, this soil is defined as free sand.

The soil textural classification was used in the RETC freeware, available on its developer site, the PC-PROGRESS ENGINEERING SOFTWARE DEVELOPER. According to the website of PC-PROGRESS, this software is used to analyze retention functions of water and hydraulic conductivity for unsaturated soils. This freeware makes use of Rosetta database (SCHAAP; LEIJ; VAN GENUCHTEN, 2001), which allows predictions of hydraulic soil parameters from textural classification.

It was observed during numerical tests of the percolation model that infiltration was above the values observed in the field. In order to bring infiltration near the observed field values, $\theta_{s}$ e $K_{s}$ (provided by RETC) were adjusted to values of $0.40 \mathrm{~cm}^{3} / \mathrm{cm}^{3}$ and $0.18 \mathrm{~cm} / \mathrm{min}$, respectively.

The equations that define the moisture content in the soil $(\theta(\Psi))$, the hydraulic conductivity $(\mathrm{K}(\theta))$ and the specific hydraulic capacity $(\mathrm{C}(\theta))$, based on the theory of van Genuchten (1980) and Mualem (1976) model are as follows:

$$
\begin{aligned}
& \theta(\Psi)=\theta_{r}+\left(\theta_{s}-\theta_{r}\right)\left[\frac{1}{1+(\alpha \Psi)^{n}}\right]^{m} \\
& K(\theta)=K_{s} \sqrt{\frac{\theta-\theta_{r}}{\theta_{s}-\theta_{r}}}\left[1-\left(1-\frac{\theta-\theta_{r}{ }^{1 / m} \theta_{r}}{\theta^{2}}\right)^{2}\right. \\
& C(\theta)=\frac{\alpha m\left(\theta_{s}-\theta_{r}\right)}{1-n} \frac{\theta-\theta_{r}}{\theta_{s}-\theta_{r}}\left(1-\frac{\theta-\theta_{r}}{\theta_{s}-\theta_{r}}\right)^{1 / m}
\end{aligned}
$$

where: $\Psi$ is the suction or pressure head $(\mathrm{cm}) ; K(\theta)$ : Hydraulic conductivity as function of soil moisture content $(\theta), \mathrm{cm} / \mathrm{min}$; $C(\Psi)$ : Specific hydraulic capacity, $d \theta / d \Psi\left(\mathrm{cm}^{2} / \mathrm{cm}^{3}\right) ; \theta$ ou $\theta(\Psi)$ : Soil moisture content, $\mathrm{cm}^{3} / \mathrm{cm}^{3}$;

$\theta_{s} e \theta_{r}:$ Saturated and residual soil water content, values equal to 0.40 e 0.057 , respectively; $K_{s}$ : Saturated hydraulic conductivity, value equal to $0.18 \mathrm{~cm} / \mathrm{min} ; \alpha, n e m$ : Soil parameters, equals to $0.124,2.28$ and 0.56 , respectively.

The graphics that describe the behavior of these equations for the DIR-Mirassol are shown in Figure 5.

In this study, it was essential to consider in the surroundings of the study area existing groundwater exploitation carried out by the local urban water supply service (CAERN).

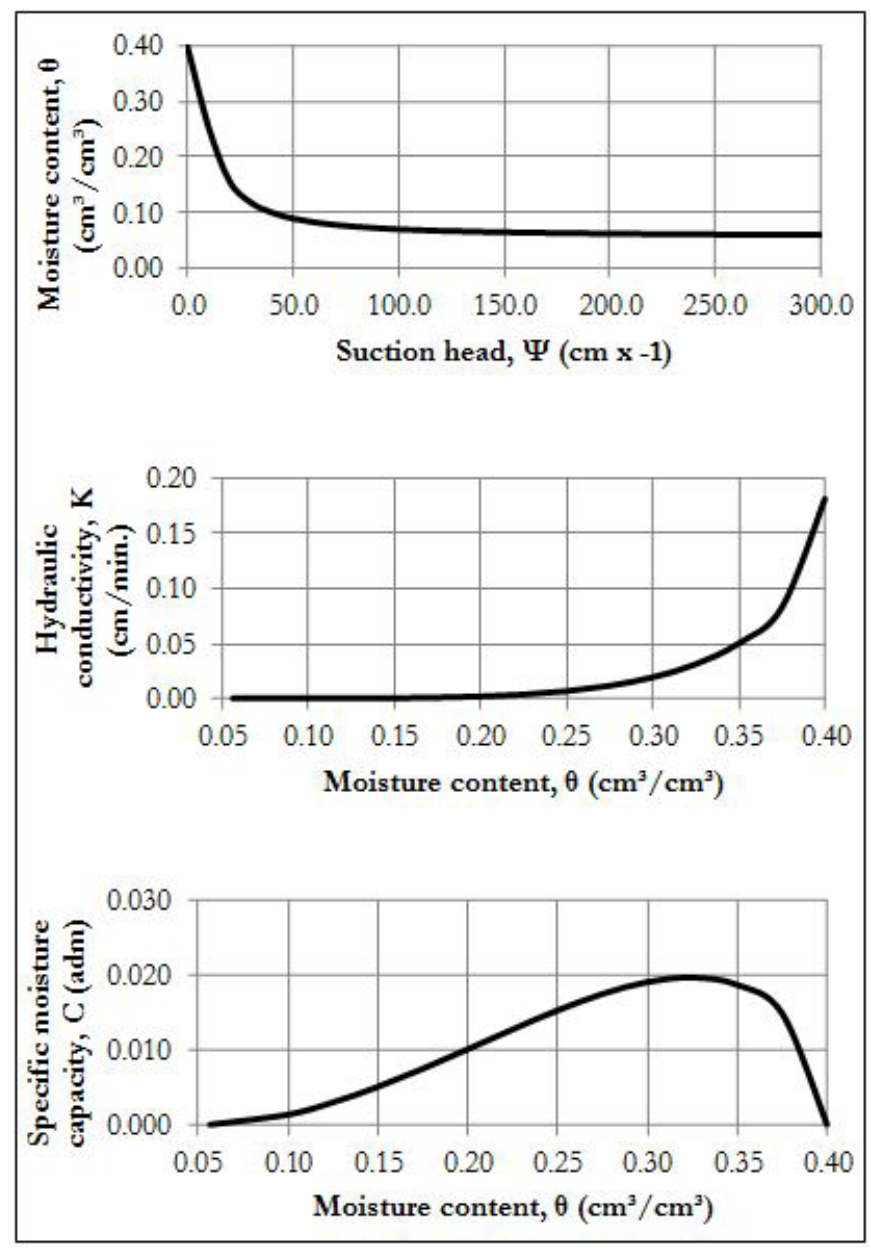

Figure 5. Soil characterization curves.

Groundwater level observations were carried out in the period from $01 / 10 / 2015$ to $23 / 11 / 2015$ (dry season) in order to determine weekly the aquifer exploitation flow (CARDOSO, 2015). On average, it was observed that the phreatic level varies approximately $-17.0 \mathrm{~cm}$ per week. With this value, the exploitation flow, q, was estimated from the test flow percolation model.

The value of $q$ resulting in a weekly decay of water table of $-17.0 \mathrm{~cm}$ was $0.001 \mathrm{~cm} / \mathrm{min}$. This value was adopted as the basis of flow exploitation to the hydrogeological study of the DIR.

\section{PROCEDURES}

The study includes monitoring precipitation, conducted in the automatic station installed in PBM as well as water level measurements in the reservoir and in phreatic aquifer.

The data were stored every minute (compatible with the discretization in time used in modeling) and monthly collected during the period from April 2014 to September 2015.

Much of this study was devoted to computer modeling process. The modeling was performed using the Microsoft Developer Studio program using the Fortran 90 programming language. The rainfall-discharge model developed by Righetto (2014) underwent changes in its input data and calibration in 
relation to the expression that defines the coefficient a runoff variation over time of occurrence of rain event.

\section{Modeling}

With the rainfall data at intervals of 1 min the modelling was processed in order to determine the discharge flow $\left(\mathrm{m}^{3} / \mathrm{min}\right)$ at any street section and then, the temporal discharge to the DIR.

The inflows to DIR, in turn, are used as input data for the one-dimensional modeling the soil profile. For each flow generated by rainfall-runoff model (including zero), it is carried out water balance of the reservoir. Coupled to the water balance model, the infiltration model and percolation of water into the unsaturated porous medium is simulated through which is determined temporal position of phreatic water level at each time interval of $1 \mathrm{~min}$.

\section{RESULTS AND DISCUSSION}

\section{Global simulation}

The evaluation of the models presented here, as well as verification of the DIR performance and estimates of groundwater recharge were done by analysis of the overall simulation over a period of 18 months (April/2014 to September/2015), with observations of rainfall and water levels in the lagoon and in the surface of the phreatic groundwater.

To overall simulation, it is set an initial condition for percolation model in unsaturated soil; so that it was assumed that the initial soil subsurface just below the reservoir is in the field capacity and, therefore, with a small reservoir bottom flow to the water table.

As initial condition $(t=0)$, it was considered that the suction head, $\Psi$ is in field capacity, $\Psi \mathrm{cc}$ equal to $-50 \mathrm{~cm}$ that happens in the reservoir bottom and the surface of the groundwater phreatic level defined by suction head equal zero. Then
$\Psi(0,0)=\Psi_{c c}=-50.00$

$\Psi\left(z_{L F}, 0\right)=0.00$

where: $z_{L F}$ is the depth of the water table. The $z$ coordinate has value equal zero in the reservoir bottom with gravity direction.

This situation defines a constant flux at field capacity; then, for $\mathrm{i}$ from 0 to $\mathrm{N}_{\mathrm{LF}-1}, \Psi(i, 0)$ values are determined by

$\Psi(i, 0)=\Psi(i+1,0)-\left(1-K_{c c} / K_{(i+1)}\right) \Delta z$

For i varying from $\mathrm{N}_{\mathrm{LF}}+1$ until NI (last domain node) the hydrostatic distribution was considered, i.e.:

$\Psi(i, 0)=\Psi(i-1, t)+\Delta z$

Over time, $\mathrm{t} \geq 0$, it was considered $\Delta t=1.0$ min. $\mathrm{P}, V_{\text {Afluente }}$ and $H_{\text {Lagoa }}$, obtained by simulating rainfall-discharge processing model in the watershed were stored to be used in the simulation of DIR water balance and soil percolation-groundwater recharge.

The last layer in the profile is considered waterproof, i.e., zero flow. The flow of exploitation was defined according to the phreatic surface level and adjusted according to values observed in a well installed beside DIR

Figures 6 and 7 provide the main results of the global simulation for the period of April to September 2014, in which the largest annual rainfall event occurred.

Each graphic was constructed in daily scale with corresponding value variables results. Precipitation, P ( $\mathrm{mm})$; Volume affluent, $\mathrm{V}_{\text {afluente }}\left(\mathrm{m}^{3} /\right.$ day); maximum daily water level in the reservoir,

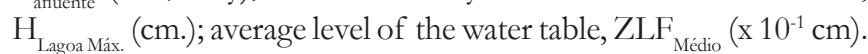

The lines corresponding to $\mathrm{P}, \mathrm{V}_{\text {afluente }}, \mathrm{H}_{\text {Lagoa Máx. }}$ and $\mathrm{ZLF}_{\text {Médio }}$ vary with time due to rainy events that occurred during the simulated period and also due to the soil saturated degree between the reservoir bottom and the phreatic surface..

In Figure 6 it is important to note that there was a relative delay in recharging process due to the fact that virtually all the

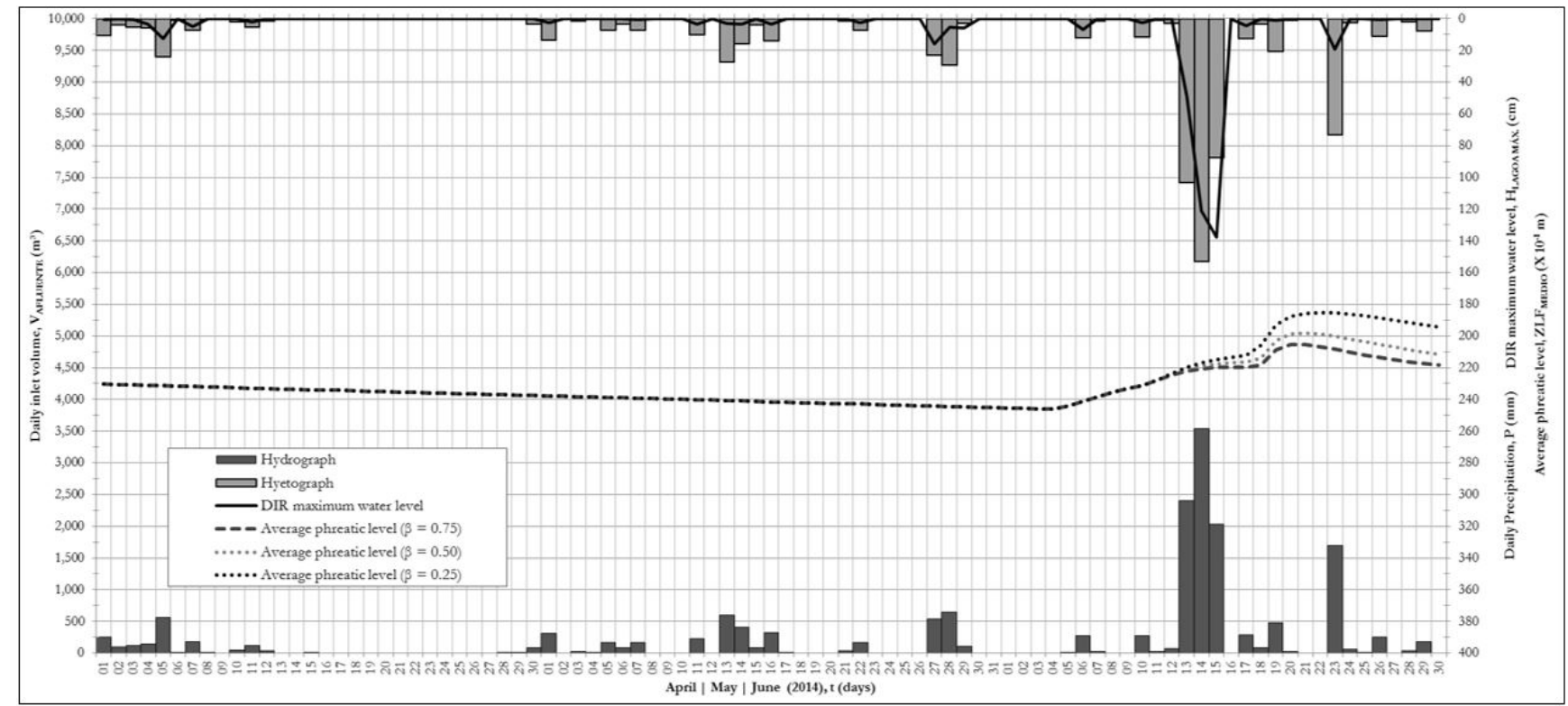

Figure 6. Global simulation results - April to June, 2014. 


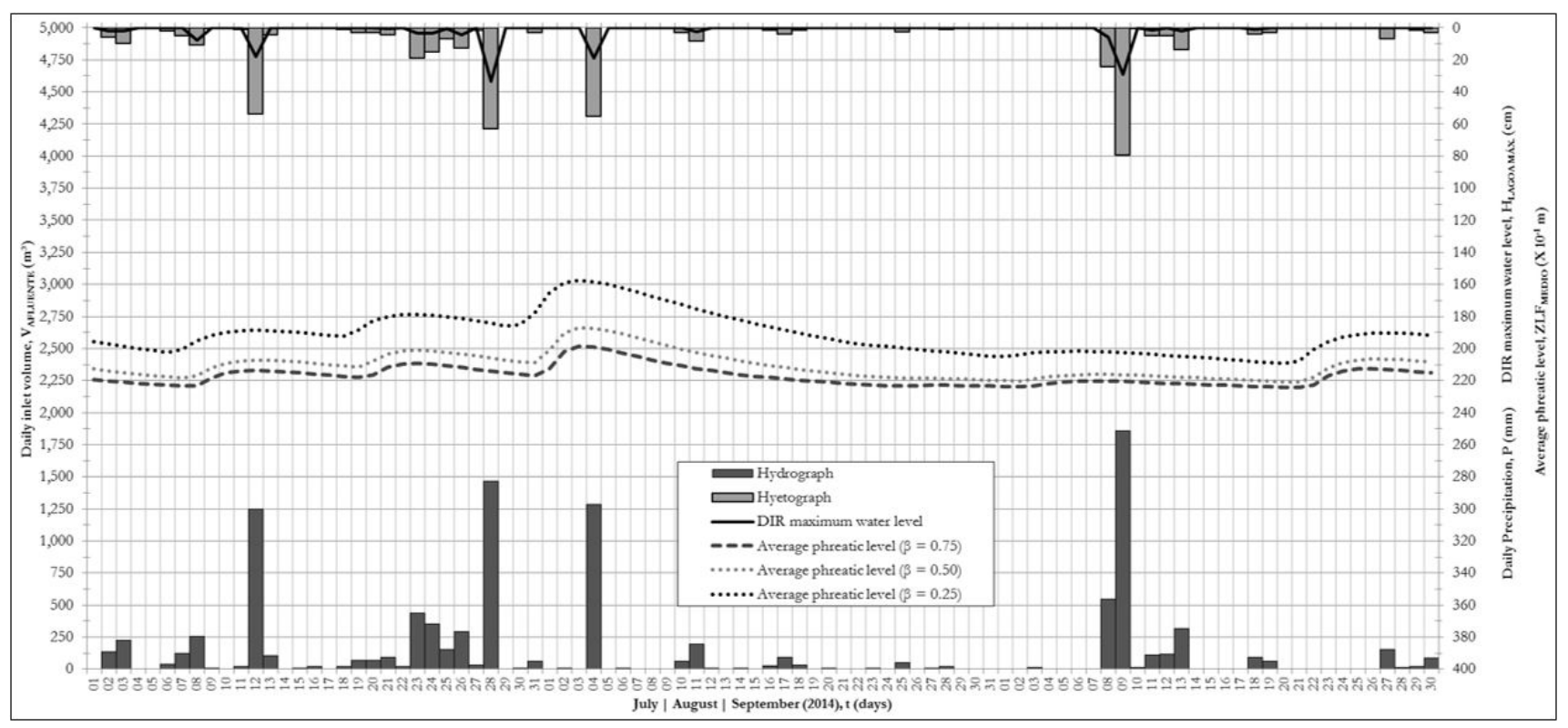

Figure 7. Global simulation results - July to September, 2014.

soil column between the pond bottom and the water table was relatively dry $(\theta \cong 0,10)$, a fact that requires a longer time to forward saturation progressed and reached the phreatic water. Therefore, within the first three months of simulation, there is the beginning of the recharge period takes place in mid-June.

Also in this figure, one should note the rainfall events that occurred between the days 06/13/2014 and 15/06/2014. These events were marked in Natal memory due to the fact of the occurrence of several flooded areas in the city and have caused serious landslide occurred on Mãe Luiza neighborhood just at the time it was being held the World Cup Soccer. For this reason, this exceptional storm in Natal is called by rain 2014 Cup.

The rain gauge installed in BPM recorded three rainfall events during this period, which amounted to $343.7 \mathrm{~mm}$ with a cumulative time of 38 hours, estimated in total as 100 years return period event.

Finally, due to the fact of the occurrence of an event of that magnitude associated with the presence of previous rainfall events contributing to the increase in the degree of saturation of the soil, it is observed that recharging began to occur 5 days after the beginning of the rainfall event. Thus, this time period between infiltration and groundwater recharge occurrence can be considered small compared to the mean time of about 20 days.

In Figure 6, it is also observed that since beginning of July until early August has increased occurrence of rainfall events.

In this period, the presence of rain increases the saturation degree in soil profile, because in short time intervals occurred accumulation of water of different events, unlike the dry period; for this reason, the aquifer recharges are more frequent and intense.

The rest of the period (Figure 7), i.e., mid-August and September (except precipitation at 08 and 09 September) it is observed the beginning of the dry season, decreasing both the frequency and the magnitude of rainy events.

In the remaining months, the simulation confirms the permanence of the dry season with lower magnitudes of rainy events throughout the observation period. However, due to the fact of the occurrence of large rainfall events and recharges that preceded this period, coupled with the presence of a few rainfall events, although of low magnitude, recharges were sufficient to prevent excessive decay of level of the phreatic water table. During this period, it is assumed that the equilibrium of the groundwater surface was maintained more by moisture redistribution than the presence of rain itself.

The estimated level in the DIR was $1.84 \mathrm{~m}$ and occurred on April 11, 2014. Although it was an event with a total of $56.4 \mathrm{~mm}$ and duration of 150 minutes, it resulted in higher reservoir water level due to the highest peak inlet discharge observed along all the simulated period.

In all simulation, the phreatic water level as a function of time is strongly influenced by the exploitation flow rate. That is, the lateral flow happens from the aquifer soil profile as a whole. Through the parameter $\beta$, the model shows greater or lesser intensity of aquifer recharge, so that the groundwater may answer more or less depending on the recharge.

Because the study focus on unidimensional recharging process, the simulations showed that, the $\beta$ parameter should assume values above 0.25 . Values below this would lead the entire soil profile become saturated during intense rainfall events and long duration. It is possible, but not observed in the time period studied.

Moreover, $\beta$ values greater than 0.75 would decrease water level excessively far superior to values of the water level observed through the observation well.

\section{Local simulation}

To better explain the behavior of the percolation of water in the soil profile, it was highlighted a period of strong recharge between day 11/04 and 21/04 2014.

Figure 8 shows the rainfall distribution and the corresponding hydrograph generated by the rainfall-discharge model. This event 


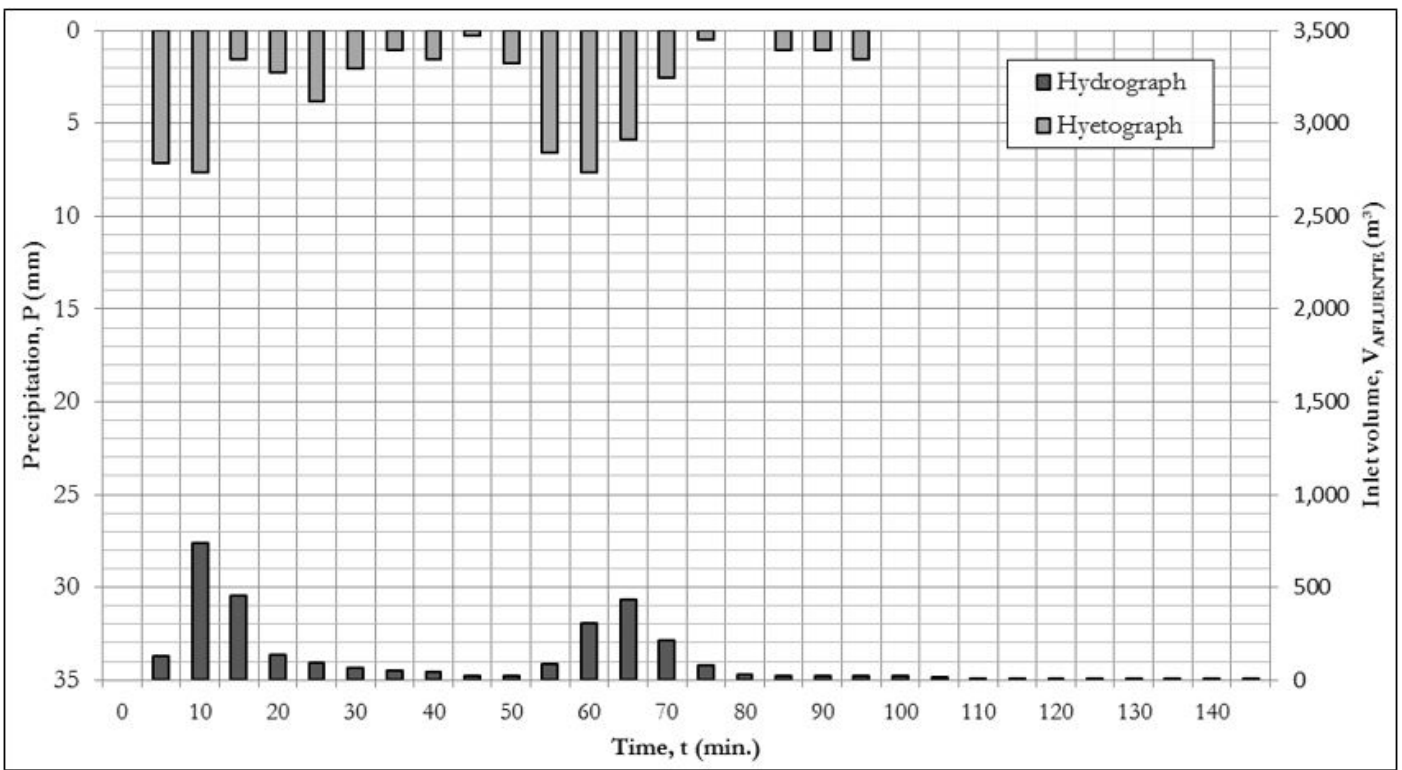

Figure 8. Observed hyetograph and simulated hydrograph.

permits to accomplish in detail the evolution of the water distribution in the soil profile. It encompasses the event occurred on 04.11.2014 in which it was estimated the highest reservoir water level. The plots referred to calculated values in a $1 \mathrm{~min}$ time intervals and averaged for $5 \mathrm{~min}$ interval.

Figure 9 shows the evolution of the moisture profile into the soil, the front of wetness over a period of 10 consecutive days from the start of the main event (04.11.2014 - 02h27 min).

At time $\mathrm{t}=0 \mathrm{~h}$, it is observable the wetting front of the main event located practically in the reservoir bottom $(Z=0.0 \mathrm{~m})$ as well as the existence of moisture front located $4.0 \mathrm{~m}$ below (from earlier rainfalls, which occurred on 8, 9 and 11 April).

Time $\mathrm{t}=16 \mathrm{~h}$ corresponds to the instant at which the reservoir empties completely. It also shows the advance of the wetting front of the main event. It is noted that the saturated soil layer reaches a thickness of approximately $6.5 \mathrm{~m}$.

At time $t=24 \mathrm{~h}$, in the reservoir bottom soil moisture returns to field capacity (upper boundary condition when the lagoon is dry) and there is the advance of the main wetness with narrowing gap between the existing fronts.

At time $\mathrm{t}=48 \mathrm{~h}$, it is noted the appearance of a wetting front above the main front due to occurrence of $2.30 \mathrm{~mm}$ and 5 minutes duration rainfall, on April 12, 2015.

At time $\mathrm{t}=120 \mathrm{~h}$, the main front wetness merges with the front of initial time, i.e., $\mathrm{t}=0 \mathrm{~h}$, besides highlighting the slow advance of the front from the day of the event (Abril 12, 2014).

In addition, in the time $t=240 \mathrm{~h}$, corresponds to the moment that begins the phreatic aquifer recharge

\section{Rainfall design simulation}

In order to assess the performance of the infiltration process that occurs in the reservoir, it was simulated an extreme storm in the PBM and thus, getting the maximum water level in the reservoir and its efficiency evaluated. It was adopted in this

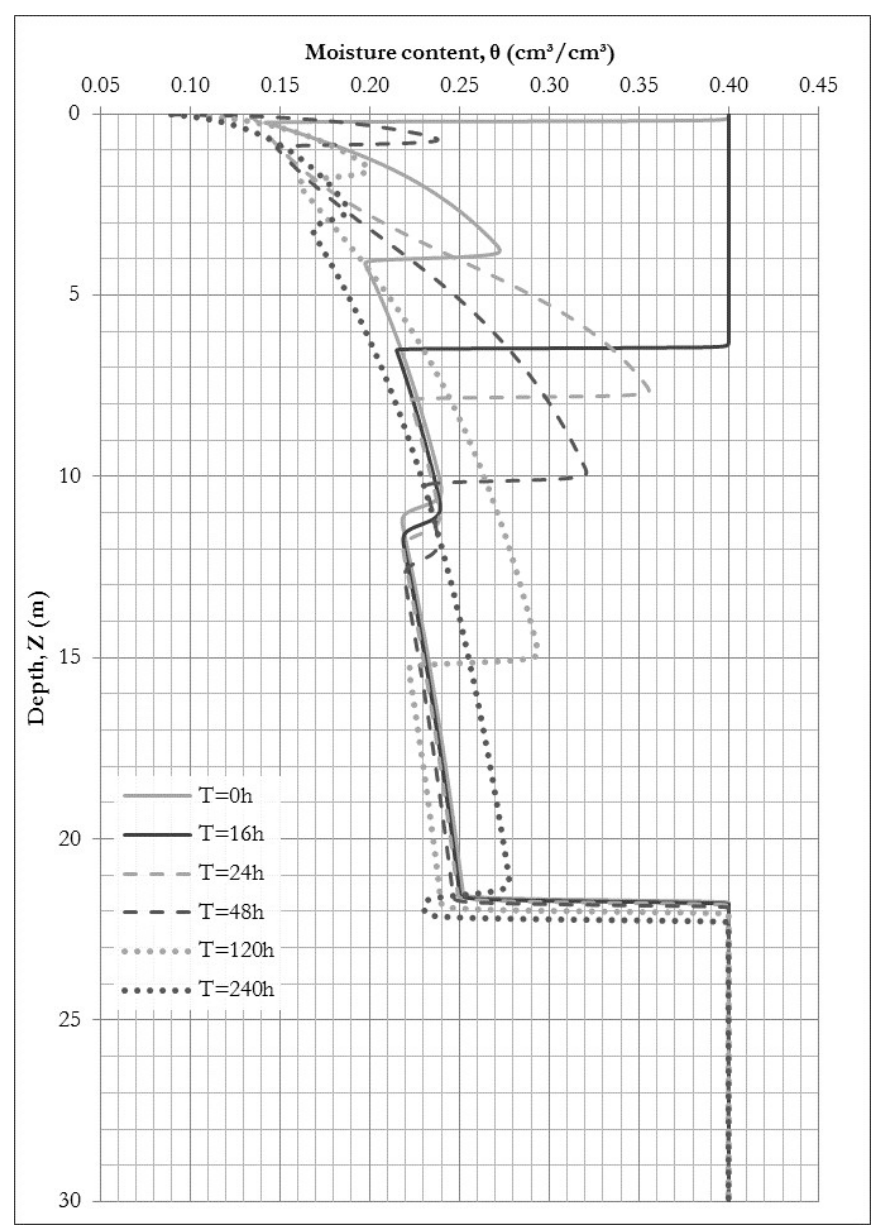

Figure 9. Evolution of soil moisture profile.

simulation a triangular rainfall distribution so that the maximum intensity positioned at half rain duration time.

The hyetograph refers to the intensity duration of 5 days and return period $\mathrm{T}=50$ years. The rainfall-discharge modeling was run for obtaining the hydrograph corresponding to 50 years 


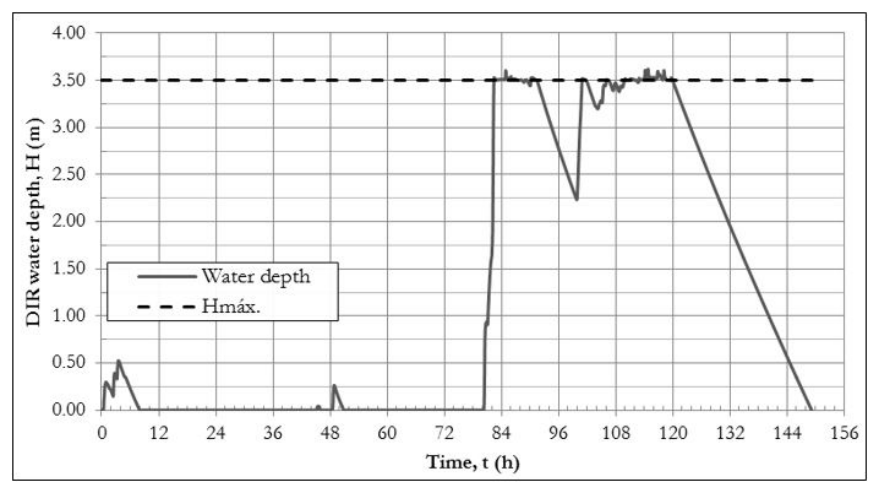

Figure 10. Water storaged in DIR-Mirassol due to rainfall event $\mathrm{i}(\mathrm{tc}=120 \mathrm{~h} ; \mathrm{T}=50$ years $)$.

return period along $120 \mathrm{~h}$. For this return period and 5 rainy days, the total rainfall is equal to $67 \mathrm{~mm}$. With these values, the reservoir water balance was simulated, considering the process of infiltration and soil percolation. By means of coupled model, the models are processed concurrently within a single calculus environment.

Figure 10 shows the time dependent water levels in the DIR-Mirassol resulting from storm rainfall i(tc, T) or i(120h, 50anos).

During this period, the maximum level can lead to flooding around the reservoir if the water transfer mechanisms are inadequate, poor or damaged.

The proper characteristic of Natal ponds in flood control is the topographic elevation of about $30 \mathrm{~m}$ above the sea level. This elevation avoid most lagoons do not become contours of the potentiometric surface of the Dunas-Barreiras aquifer, preserving the high infiltration capacity of LDI.

\section{Rainfall-discharge model test}

The rainfall-discharge processing flow model was calibrated from data collected from rain gauge and stage measurements at DIR-Mirassol. The events used for this calibration were the daily rainfall that occurred in January 5, $2015(\mathrm{P}=29.46 \mathrm{~mm})$ and the rainfall of June 24-25, 2015 ( $\mathrm{P}=70.87 \mathrm{~mm})$.

Due to the complexity of the model and variation of parameters over time, the best calibration resulted in variations in the range of $\pm 20.0 \%$, or $30 \mathrm{~mm}$, i.e., for events of $30 \mathrm{~mm}$ rainfall, the model increased the discharge values of about $20 \%$ e rainfall of $70 \mathrm{~mm}$ the discharges were decreased to values less than $20 \%$ of observed.

\section{Percolation and water balance model test}

The unidimensional percolation model discretized on time $(1 \mathrm{~min})$ and space $(2.0 \mathrm{~cm})$ was used to perform the overall simulation with 1,500 nodes and 777,600 time intervals in an approximate processing time of $11 \mathrm{~min}$. The computational processing was run in a personal computer Core i7 with $2.2 \mathrm{GHz}, 6 \mathrm{~GB}$ RAM, using FORTRAN programming language.

Disregarding surface evaporation losses, detention surface and lateral infiltration, the overall simulation showed a loss or error of $2.88 \%$ in water balance, as shown in the following evaluation:
$S=V_{M 1}-\left(V_{M 2}-V_{\min }\right) \equiv 0,00$

$S=63,905.33-(67,397.78-5,333.01)$

$S \cong 1840.56 \mathrm{~m}^{3}$

$\operatorname{Loss}(\%)=100 \frac{S}{V_{M 1}}=100 \frac{1,840.56}{63,905.33}=2.88$

where: $V_{M I}$ : Total runoff obtained by the rainfall-discharge model; $V_{M 2}$ : Total recharge to phreatic water table obtained by the percolation model; $V_{\text {min. }}$ : Total volume infiltrated by field capacity condition; $S$ : Water balance.

This error can be attributed to the temporal discretization process and by restricting water content to values larger than field capacity, which maintain residual flow even in the condition of dry reservoir.

\section{CONCLUSION}

The integrated model (rainfall-runoff-storage-infiltrationrecharge) developed for PBM proved to be effective and easy to use as tool for the analysis of drainage systems involving hydraulic infrastructure and LID installation.

The hydrological simulations over a sequence of $1 \mathrm{~min}$ time intervals and eighteen months duration showed adequate to evaluate flood control of Mirassol reservoir as well as infiltration and percolation of water to phreatic aquifer.

Two main aspects of the reservoir worth mentioning in relation to damping storage water despite its relatively small volume capacity: high hydraulic conductivity of the soil and position of the phreatic water table.

The infiltration capacity is high because the lagoon is located over dune formation and has adequate topography once the water table depth does not reach values that might compromise infiltration and reduction of water storaged in the reservoir.

However, in situations of high intensity and persistent rainy days, it is expected that all the region could contribute to the recharge and, in this situation, the lagoon can become ineffective and vulnerable to flooding. This fact occurs in several lagoons in the city of Natal, the ones located in lower elevation relative to sea level.

In the construction of percolation model, the parameter $\beta$ was introduced to consider the lateral dispersion of the infiltrated water. This parameter is highly sensitive to lower or increase the variation of the water table and thus the infiltration process and recharging.

It is important to emphasize that the design and detention reservoir operation should consider the existence of groundwater and its influence on the infiltration process.

It is noteworthy that the pond emptying time for persistent rainfall events significantly alter its infiltration capacity. With the presented model, it is possible to evaluate the operation of DIR for the case of intense and successive rainy days.

Regarding the rainfall-runoff model, the natural complexity of the drainage basin was considered and relatively simplified. The division of drainage area into blocks and streets and, from 
the topographic characterization, the structural topology between them, it is easily applied to any urban watershed.

This spatial division enabled the construction of a distributed hydrologic model that considers precipitation over blocks and streets. In the blocks, due to the accumulated water volume, runoff law temporally quantifies the affluent side flows to the streets. In addition, in every street section, the water balance of inflows and stored volumes of water determines the effluent flow to the downstream street section or to the watershed outlet.

Because it is a relatively simple algorithm, it is easily modifiable to include other features of the hydrologic process, such as water retention in appropriate areas and to consider the sediment and contaminant transport in the basin, favoring the quantitative and qualitative management of the hydrological and environmental system.

The water balance in the DIR, based on coupling of inflows to the volumes stored and percolation of water in the soil allows evaluating temporally the recharging process to the water table aquifer.

The simulations demonstrated the efficiency and versatility of the calibrated model to evaluate the temporal distribution of varying contributions of runoffs in the basin. Measurements of the reservoir water level were used to calibrate the hydrological model. Due to rough calibration, it was estimated an error of about $20 \%$ between two events observed when compared to the corresponding simulated hydrographs.

The model is particularly interesting for the operational management of drainage systems, especially when considering the length of time between two rainfall events and the drainage capacity by the DIR.

When the catchment is not completely occupied, the increasing process of waterproofing can lead to frequent failures in the storage of water by the reservoir and then, additional instruments for emptying the lagoon become necessary as, for example, the introduction of batteries of infiltration wells or pumping station to transfer part of the stored water. In such cases, the model presented here is an effective tool for decision making in relation to the system.

Of course, the work presented here opens up prospects of development of new research in the pilot drainage basin.

As future work proposal, we suggest the following:

(i) Continuity of observations of rainfall and water levels in the lagoon and aquifer;

(ii) Implementation of appropriate measurement of discharge from the PBM;

(iii) Carrying out tests for survey of the main hydrological parameters;

(iv) Understand and quantify the percolation of lateral flow as function on the depth of the water table;

(v) Three-dimensional hydrogeological modeling;

(vi) Sediment transport and wash load research in the PBM, as well as the management of the proper use of the lots due to runoffs and wastewater effluent discharges.
In the case of an urban pilot basin is unquestionable the recommendation of continuity monitoring, the introduction of automated measurements of the groundwater water levels to allow the development of hydrological and hydrogeological modeling. Also, it should be implemented a three-dimensional domain so as to understand in detail the process of infiltration, percolation and redistribution of water in soil and groundwater; mainly as the evaluation of the regional porous media flow during rainy periods.

\section{ACKNOWLEDGEMENTS}

To FINEP for the financial support to the project development MAPLU 2 - Process 01.10.0701.00. The authors thank CAPES for institutional scholarship master-PPgES-UFRN; and $\mathrm{CNPq}$ for research productivity scholarship to the first author.

\section{REFERENCES}

AMANTHEA, N. R.; NASCIMENTO, N. O. Urbanização de baixo impacto (LID): uso de geotecnologias para estimativa do tempo de concentração de bacia em cenário de pré-desenvolvimento. Revista Brasileira de Recursos Hídricos, v. 20, n. 1, p. 249-266, 2015. http://dx.doi.org/10.21168/rbrh.v20n1.p249-266.

CARDOSO, B. F. Desempenho de uma lagoa de infiltração na absorção de cheias e na recarga de aquífero. 2015. 66 f. Dissertação (Mestrado em Engenharia Sanitária)-PPgES, Universidade Federal do Rio Grande do Norte, Rio Grande do Norte, 2015.

JAMES, W.; ROSSMAN, J. L. E.; JAMES, W. R. C. User's guide to SWWM 5: water system model. Guelph: CHI, 2010. 905 p.

LIMA, R. R. M. Estudo de manejo de águas pluviais Urbanas na cidade de Natal-Rio Grande do Norte. 2011. 191 f. Dissertação (Mestrado em Engenharia Sanitária)-PPgES, Universidade Federal do Rio Grande do Norte, Rio Grande do Norte, 2011.

LIMA, R. R. M.; RIGHETTO, A. M. Utilização do modelo SWMM. In: CASTRO, M. A. F.; REIS, L. F. R.; RIGHETTO, A. M. (Org.). Engenharia de águas urbanas. Fortaleza: Expressão Gráfica, 2013. cap. 1. p. 13-48.

MUALEM, Y. A new model for predicting the hydraulic conductivity of unsaturated porous media. Water Resources Research, v. 12, n. 3, p. 513-522, 1976. http://dx.doi.org/10.1029/WR012i003p00513.

NATAL. Plano Diretor de Drenagem e Manejo de Águas Pluviais do Município do Natal - PDDMA. Manual de Drenagem da cidade de Natal - RN. Natal, 254 p. 2009. Relatório.

REEDER, J. W.; FREYBERG, D. L.; FRANZINI, J. B.; REMSON, I. Infiltration under rapidly varying surface water depths. Water Resources Research, v. 16, n. 1, p. 97-104, 1980. http://dx.doi. org/10.1029/WR016i001p00097.

REZENDE, O. M.; MIGUEZ, M. G.; VERÓL, A. P. Manejo de águas urbanas e sua relação com o desenvolvimento urbano 
em bases sustentáveis integradas: estudo de caso dos Rios PilarCalombé, em Duque de Caxias/RJ. Revista Brasileira de Recursos Hídricos, v. 18, n. 2, p. 149-163, 2013. http://dx.doi.org/10.21168/ rbrh.v18n2.p149-163.

RIGHETTO, A. M. Hidrologia e recursos hídricos. São Carlos: Departamento de Hidráulica e Saneamento, EESC/USP, 1998. 840 p.

RIGHET'TO, A. M. Relatório descritivo do processo de transformação de chuva em vazão. In: FINANCIADORA DE ESTUDOS E PROJETOS - FINEP. (Org). Manejo de águas pluviais urbanas: MAPLU. Natal: UFRN, 2014. 20 p.

RIGHETTTO, A. M.; MOREIRA, L. F. F.; SALES, T. E. A. Manejo de águas pluviais urbanas. In: FINANCIADORA DE ESTUDOS E PROJETOS - FINEP. Programa de Pesquisas em Saneamento Básico - PROSAB. (Org.). Manejo de águas pluviais urbanas. 1 st ed. Rio de Janeiro: ABES, 2009a. v. 4, cap. 1, p. 19-73.

RIGHETTO, A. M.; ANDRADE NETO, C. O.; BRITO, L. P.; SALES, T. E. A.; MOREIRA, L. F. F. Estudo qualiquantitativo e de manejo de águas pluviais em área de drenagem piloto na cidade de Natal - RN. In: FINANCIADORA DE ESTUDOS E PROJETOS - FINEP. Programa de Pesquisas em Saneamento Básico - PROSAB. (Org.). Manejo de águas pluviais urbanas. 6th ed. Rio de Janeiro: ABES, 2009b. v. 4, cap. 1, p. 218-255.

SCHAAP, M. G.; LEIJ, F. J.; VAN GENUCHTEN, M. T. Rosetta: a computer program for estimating soil hydraulic parameters with hierarchical pedotransfer functions. Journal of Hydrology, v. 251, n. 3-4, p. 163-176, 2001. http://dx.doi.org/10.1016/S00221694(01)00466-8.
SOUZA, C. F.; CRUZ, M. A. S.; TUCCI, C. E. M. Desenvolvimento urbano de baixo impacto: planejamento e tecnologias verdes para a sustentabilidade das águas urbanas. Revista Brasileira de Recursos Hidricos, v. 17, n. 2, p. 9-18, 2012. http://dx.doi.org/10.21168/ rbrh.v17n2.p9-18.

TAVANTI, D. R.; BARBASSA, A. P. Análise dos desenvolvimentos urbanos de baixo impacto convencional. Revista Brasileira de Recursos Hídricos, v. 17, n. 4, p. 17-28, 2012. http://dx.doi.org/10.21168/ rbrh.v17n4.p17-28.

TUCCI, C. E. M. Inundações urbanas. 1st ed. Porto Alegre: ABRH/ RHAMA, 2007. 393 p.

VAN GENUCHTEN, M. T. H. A closed-form equation for predicting the hydraulic conductivity of unsaturated soils. Soil Science Society of America Journal, v. 44, n. 5, p. 892-898, 1980. http://dx.doi.org/10.2136/sssaj1980.03615995004400050002x.

\section{Authors contributions}

Antonio Marozzi Righetto: Research coordinator; participation in mathematical modeling, simulation and production of the article participation.

Bruno Freitas: Conducted field experiments and data collection; participation in mathematical modeling, simulation and production of the article. 